Article

\title{
Efficacy of Ultrasonic-Assisted Curing Is Dependent on Muscle Size and Ultrasonication System
}

\author{
Bianka Y. Cruz-Garibaldi ${ }^{1}$, Alma D. Alarcon-Rojo ${ }^{1} \mathbb{D}$, Mariana Huerta-Jimenez ${ }^{1,2}{ }^{\oplus}$, \\ Ivan A. Garcia-Galicia ${ }^{1}$ (D) and Luis M. Carrillo-Lopez ${ }^{1,2, *(D)}$
}

1 Faculty of Animal Science and Ecology, Autonomous University of Chihuahua, Perif. Francisco R. Almada km. 1, Chihuahua, Chih 31453, Mexico; p334599@uach.mx (B.Y.C.-G.); aalarcon@uach.mx (A.D.A.-R.); mhuertaj@uach.mx (M.H.-J.); igarciag@uach.mx (I.A.G.-G.)

2 Cátedras CONACYT, National Council of Science and Technology, Av. Insurgentes Sur 1582, Col. Crédito Constructor, Del. Benito Juárez, Ciudad de México 03940, Mexico

* Correspondence: lmcarrillo@uach.mx; Tel.: +52-595-112-3693

Received: 24 July 2020; Accepted: 17 August 2020; Published: 20 August 2020

\begin{abstract}
Ultrasound-assisted marinade is a promising technology for reducing the time of traditional immersion marination. This study evaluated the effect of the ultrasonic system (bath or probe, amplitude 50 or $100 \%$ ) and muscle sample size $\left(3\right.$ or $\left.5 \mathrm{~cm}^{3}\right)$ on physicochemical quality, yield (salt content, fresh weight, and relative fresh weight), and bacteria counts associated with pork. The results showed a significantly high salt $(p<0.0001)$ content in $3 \mathrm{~cm}^{3}(11.54 \%)$ and $5 \mathrm{~cm}^{3}(8.88 \%)$ samples after $24 \mathrm{~h}$ marination by immersion. The $3 \mathrm{~cm}^{3}$ cubes marinated in a $100 \%$ probe system for $20 \mathrm{~min}$ presented an amount of salt (9.55\%) that was quite close to the controls. The $3 \mathrm{~cm}^{3}$ samples treated by immersion and in a 50\% probe system gained more relative weight (in relation to the initial weight, 7.45 and $6.64 \%$, respectively) after $7 \mathrm{~d}$ at $4{ }^{\circ} \mathrm{C}$. Meanwhile the $5 \mathrm{~cm}^{3}$ cubes marinated by immersion gained $8.1 \%$. The other treatments showed a weight loss after treatment. Although significant differences were found in the fresh weight and in water holding capacity (WHC) in the 3 and $5 \mathrm{~cm}^{3}$ meat samples, the relative fresh weight is a real measure of weight gain, more relevant for the industry. Thus, the samples with the highest salt transfer experienced a phenomenon of "dehydration", retaining less water. The 3 and $5 \mathrm{~cm}^{3}$ cubes marinated by immersion presented orange color tones due to the long processing time, while the probe system produced redder and brighter tones. Ultrasound as a technology to assist in marinades is not efficient for bacteria control of mesophilic, psychrophilic, or coliform. However, a significant increase in lactic acid bacteria (LAB) counts may bring benefits for meat preservation during refrigerated storage.
\end{abstract}

Keywords: cured meat; high-intensity ultrasound; relative fresh weight; microbiota

\section{Introduction}

Marination of meat consists of the incorporation of ingredients to the raw meat, mainly salts. However, other additives such as sugar, organic acids, and/or spices can be added as flavorings and colorants that diffuse through the osmosis process towards the interior of the meat [1,2]. Traditional meat marination requires a minimum time of $12 \mathrm{~h}$ to ensure that solutes migrate efficiently into the muscle, so novel techniques are needed to accelerate the absorption process and decrease microstructural damage due to long times of marination [3]. Salt $(\mathrm{NaCl})$ is the primary ingredient in brine because it increases meat tenderization and it can be a flavoring attribute from a sensory point of view. However, recent regulatory measures have resulted in decreased salt intake due to health problems associated with sodium. In this regard, studies with high-intensity ultrasound have demonstrated its effectiveness to achieve homogeneous distribution profiles and higher percentages of sodium in beef. 
Therefore, ultrasound is a promising technology for the reduction of marination times and acceptable improvement of low sodium products, the latter due to the uniformity distribution of salt inside the muscle [4]. This phenomenon has been explained as a "sponge effect", in which pressure fluctuations between compression cycles and rarefaction of the sound wave leads to a better distribution of the brine within the meat [5]. Ultrasound is a physical phenomenon whose effects are due to the production of cavitation. This consists in the formation of bubbles that grow and implode, causing damage to the muscular and microchannel structure, allowing the brine to go into the muscle. This affects the physicochemical properties such as tenderness and water-holding capacity [6,7]. Due to the potential benefits offered by ultrasound to assist traditional meat marination, the latest studies have focused on evaluating both bath and probe ultrasonication systems, primarily in beef, bovine, and poultry. However, there is wide heterogeneity in the parameters used (ultrasonic system, frequencies, intensities, times, salt concentrations, etc.). This makes it difficult to obtain conclusive results that allow for scaling-up this technology to industrial levels. An example of this is the use of intensities as high as $54-61 \mathrm{~W} / \mathrm{cm}^{2}[5]$ and as low as $2-4 \mathrm{~W} / \mathrm{cm}^{2}$ [8], finding in both cases a positive effect on salt transfer. Another example is the study carried out by Inguglia et al. [3], who found a significantly higher absorption in chicken breasts treated with ultrasound in a bath system $(25,45$, and $130 \mathrm{kHz}$ and $4.7,5.5$, and $7.2 \mathrm{~W}$, respectively), reaching the desired absorption in just $1 \mathrm{~h}$ compared to $4 \mathrm{~h}$ of traditional marinade. Meanwhile, similar results were reported by Kang et al. [6] in beef treated with different intensities of ultrasound (US) (150-300 W) and salt concentrations (3-6\%). They used an ultrasonic probe system (30-120 $\mathrm{min}$ ) and found an increase of $\mathrm{NaCl}$ and water absorption in the treated meat, as well as higher interfibrillary space as the ultrasound intensity increased. Despite the discrepancy of the results, most studies have shown that ultrasound decreases marination times when compared to the traditional immersion system, regardless of the parameters used [9-12]. In order to elucidate the effect of the ultrasonic system used and the sample size during marination of pork, a completely randomized experiment was designed to evaluate salt transfer. This study provided additional advantages of ultrasound as a marinade-assisted technology. Yield (weight gain and/or loss), color, and bacteria growth were measured.

\section{Materials and Methods}

\subsection{Sample Origin and Treatments}

Pork leg meat from four animals was obtained from a local processor (Grupo Bafar S.A. de C.V., Chihuahua, Mexico) at $24 \mathrm{~h}$ post mortem. Two muscles were used: the m. Semimembranosus, and the $\mathrm{m}$. Gluteus medius. They were cut into 5 and $3 \mathrm{~cm}^{3}$ cubes, having a total of 24 samples considering 3 repetitions and eight treatments. Due to the cube's dimensions, those were acquired undifferentiated. Hence, cubes were composited by $\mathrm{m}$. Semimembranosus and $\mathrm{m}$. Gluteus medius, indistinctly. At the reception, connective tissue and visible fat were trimmed and the meat was stored at $-20^{\circ} \mathrm{C}$ until further used. Thawing was performed at $4 \pm 2{ }^{\circ} \mathrm{C}$ for $48 \mathrm{~h}$ and the treatments were completely randomized assigned.

One liter of $17 \%$ basic brine containing sodium chloride and sodium phosphate was used for the marinade. Two high-intensity ultrasound (HIU) treatments (ultrasonic bath system or ultrasonic probe) were used and the marinating time was $20 \mathrm{~min}$ (10 $\mathrm{min}$ per sample side). The temperature was kept constant during the marination, at $4 \pm 2{ }^{\circ} \mathrm{C}$. Eight ultrasonic treatments were applied. Four of them used a Hielscher UP400St ultrasonic processor system (50 and $100 \%$ amplitude, $24 \mathrm{kHz}, 400 \mathrm{~W}$ in continuous mode), two treatments in a bath system ( $37 \mathrm{kHz}$ and $22 \mathrm{~W} \times \mathrm{cm}^{-2}$, Elmasonic $\left.\mathrm{S} 60 \mathrm{H}\right)$ and two in a traditional immersion marinade system $\left(24 \mathrm{~h}\right.$ at $\left.4{ }^{\circ} \mathrm{C}\right)$ and distributed as follows: (1) $3 \mathrm{~cm}^{3}$ samples in HIU bath; (2) $5 \mathrm{~cm}^{3}$ samples, in HIU bath; (3) $3 \mathrm{~cm}^{3}$ samples in ultrasonic processor (probe) with $50 \%$ amplitude; (4) $5 \mathrm{~cm}^{3}$ samples in ultrasonic processor (probe) with $50 \%$ amplitude; (5) $3 \mathrm{~cm}^{3}$ samples in ultrasonic processor (probe) with $100 \%$ amplitude; (6) $5 \mathrm{~cm}^{3}$ samples in ultrasonic processor (probe) with $100 \%$ amplitude; (7) $3 \mathrm{~cm}^{3}$ samples marinated by immersion for $24 \mathrm{~h}$ at $4{ }^{\circ} \mathrm{C}$; and (8) $5 \mathrm{~cm}^{3}$ 
samples marinated by immersion for $24 \mathrm{~h}$ at $4{ }^{\circ} \mathrm{C}$. After the marination, the samples were vacuum packed and stored at $4{ }^{\circ} \mathrm{C}$ for $7 \mathrm{~d}$. After the storage period, the sample bags were opened to evaluate the physicochemical and microbiological variables.

\subsection{Determination of Chloride}

Mohr's methodology [13] was used to determine the percentage of salt (chlorides) in all samples after $7 \mathrm{~d}$ of storage at $4{ }^{\circ} \mathrm{C}$. Twenty-five grams of sample were homogenized in a beaker containing $50 \mathrm{~mL}$ of distilled water and brought to boil. The sample solution was filtered (Whatman No. 4 filter paper) after being cooled, and transferred to a $100 \mathrm{~mL}$ volumetric flask. Five milliliters of the filtrate were taken in a $125 \mathrm{~mL}$ Erlenmeyer flask and three drops of $\mathrm{K}_{2} \mathrm{Cr}_{2} \mathrm{O}_{7}$ were added. Finally, the sample was titrated with a $0.1 \mathrm{~N} \mathrm{AgNO}_{3}$ solution, until an orange color solution was obtained. The percentage of salt was calculated by triplicate.

\subsection{Water Holding Capacity (WHC)}

WHC of meat samples was determined after $7 \mathrm{~d}$ of storage at $4{ }^{\circ} \mathrm{C}$, using the compression technique proposed by Tsai and Ockerman [14]. A $0.3 \pm 0.1 \mathrm{~g}$ sample was placed between two filter papers (Whatman No. 1). The meat in the filter paper was placed between two metacrylate plates and a constant weight of $10 \mathrm{~kg}$ was applied for $5 \mathrm{~min}$. The WHC was calculated using the following equation:

$$
\begin{gathered}
\text { WHC }(\%)=100-\text { free water } \\
\text { Free water }=\left(\frac{\text { final weight of filter paper }- \text { initial weight of filter paper }}{\text { sample }}\right) * 100
\end{gathered}
$$

The sample weight was determined with an analytical balance with precision of $0.0001 \mathrm{~g}$.

\subsection{Color Measurement}

Color was measured using a Minolta colorimeter (CR-400, Konica Minolta Sensing, Inc., Osaka, Japan; Illuminant $C, 2^{\circ}$ observer angle of measurement), based on the color coordinates $L^{*}, a^{*}, b^{*}, C^{*}$, and $\mathrm{H}^{\circ}$ according to the methodology outlined in the American Meat Science Association (AMSA) manual [15]. Color values were expressed as $L^{*}$ (lightness/darkness), $a^{*}$ (redness/greenness), $b^{*}$ (yellowness/blueness), $\mathrm{C}^{*}($ chroma or saturation $)=\left(\mathrm{a}^{* 2}+\mathrm{b}^{* 2}\right)^{1 / 2}$, and $\mathrm{H}^{\circ}$ (hue angle $)=\arctan \left(\mathrm{b}^{*} / \mathrm{a}^{*}\right)$.

\subsection{Microbiological Analysis}

Microbiological determination was carried out using the plate counting technique for psychrophilic, mesophilic, total coliform, and lactic acid bacteria (LAB). One milliliter of exudate from each vacuum packed sample was collected and diluted from 1:10 to 1: 1,000,000 using a sterile diluent (peptone water prepared with $0.1 \mathrm{~g} / \mathrm{L}$ peptone). One thousand $\mu \mathrm{L}$ of each solution were inoculated into the specific medium described below using the plate pour technique. In samples with a shortage of exudate after storage at $4{ }^{\circ} \mathrm{C}, 1 \mathrm{~g}$ of sample was taken and placed in sterile bags (Lab Plas, $4 \times 6$ inches) and homogenized in a Stomacher ${ }^{\circledR} 80$ (Seward) using $9 \mathrm{~mL}$ of $0.1 \%$ peptone water. Nutrient agar (CM0325, Oxoid, Basingstoke, UK) was used for the determination of mesophilic and psychrophilic bacteria. Aerobic incubation was carried out at $35 \pm 2{ }^{\circ} \mathrm{C}$ for $48 \pm 2 \mathrm{~h}$ and $4 \pm 2{ }^{\circ} \mathrm{C}$ for $168 \mathrm{~h}$, respectively. Red-violet glucose bile agar culture medium (CM0485B, Oxoid, Basingstoke, UK) was used for total coliforms. To favor the growth of optional coliforms, a $5 \mathrm{~mL}$ overlay was placed once the squares solidified, following the technique described by Feng et al. [16]. The plates were incubated at $35 \pm 2{ }^{\circ} \mathrm{C}$ for $48 \pm 2 \mathrm{~h}$. Agar De Man, Rogosa, and Sharpe culture medium (MRS, CM0361; Oxoid, Basingstoke, UK) was used for LAB. The incubation was carried out at $30^{\circ} \mathrm{C}$ for $120 \mathrm{~h}$. The traditional method was used (using a candle that exhausted the oxygen in the medium) to favor anaerobic conditions. To calculate the colony-forming units $(\mathrm{CFU} / \mathrm{mL})$, the number of colonies was multiplied by the dilution 
factor. The results in colony-forming unit/mL $(\mathrm{CFU} / \mathrm{mL})$ were transformed logarithmically $\left(\log _{10}\right)$ before the statistical analysis.

\subsection{Statistical Analysis}

Physicochemical and microbiological variables were analyzed using the statistical program SAS 9.4 TS Level 1M1 (SAS Institute Inc., Cary, NC, USA). The data were analyzed in a completely randomized design where the experimental unit was the pork sample (cube). Separate statistical analyses were performed for each cube size (one for $3 \mathrm{~cm}^{3}$ and one for $5 \mathrm{~cm}^{3}$ ), in order to have homogeneous experimental units and more conclusive results. Tukey tests were performed to compare means when significance was detected $(p<0.05)$.

\section{Results and Discussion}

\subsection{Salt Content and Water Holding Capacity (WHC)}

The salt content showed significant statistical differences among treatments, regardless of the sample size ( 3 or $5 \mathrm{~cm}^{3}, p<0.0001$ ). The $3 \mathrm{~cm}^{3}$ cubes of meat marinated by immersion for $24 \mathrm{~h}$ had a higher amount of salt $(11.54 \%)$. Although the cubes treated with ultrasound did not match the amount of salt in the controls, those marinated with a probe and an amplitude of $100 \%$ presented an amount of $\mathrm{NaCl}$ relatively close to the controls $(9.55 \%)$. The bath and probe with $50 \%$ amplitude were the least efficient for the transfer of salts into the muscle $(7.82$ and $6.55 \% \mathrm{NaCl}$, respectively). Inguglia et al. [3] reported similar results. They found a higher rate of sodium absorption in chicken samples marinated by immersion for $24 \mathrm{~h}(0.77 \% \mathrm{Na})$, compared to the samples treated with ultrasound. Despite the fact that the ultrasound marinating times were higher than ours $(1,3$, and $6 \mathrm{~h})$, the maximum amount of $\mathrm{Na}$ in chicken was $0.6 \%$, using brine with $8 \% \mathrm{NaCl}$. Contrary to the results of the present study, Turhan et al. [1] reported that ultrasound $\left(20,25\right.$, and $30 \mathrm{~W} / \mathrm{cm}^{2} ; 10,20$, and $\left.30 \mathrm{~min}\right)$ accelerated the transport of $\mathrm{NaCl}$ in anchovy fillets. They observed a higher content of salt as the ultrasonic intensity and time increased, whereas marinated controls (dip marinade) showed less salt content, probably due to the short immersion times used $(10,20$, and $30 \mathrm{~min})$. The behavior was different for the $5 \mathrm{~cm}^{3}$ cubes. Again, the controls (cubes marinated by immersion) presented the highest amount of salt $(8.88 \%)$. However, the $50 \%$ probe treatment was the closest to the controls $(5.86 \%)$, while the bath and $100 \%$ probe treatments were the least efficient in salt transfer (4.59 and 4.03, respectively). This suggests that when the meat size is larger $\left(5 \mathrm{vs} .3 \mathrm{~cm}^{3}\right)$, the mass transfer from the brine is slower. Thus, it is necessary to increase the processing time, either by immersion or with the assistance of ultrasound. Therefore, the $20 \mathrm{~min}$ ultrasound-assisted marinade treatment is not enough to achieve the absorption achieved with traditional marinade. Thus, under the experimental conditions of this research, it is necessary to increase the ultrasound marinade time in the $5 \mathrm{~cm}^{3}$ samples. Inguglia et al. [3] used $40 \mathrm{~g}$ chicken breast fillets during assisted marinating with an ultrasonic bath $(25,45$, and $130 \mathrm{kHz})$, Hence, times of 1,3 , and $6 \mathrm{~h}$ were sufficient to achieve a higher percentage of $\mathrm{NaCl}$, compared to marinating by immersion. In the present study, the thickness of the samples was $5 \mathrm{~cm}$, so $20 \mathrm{~min}$ was not sufficient to achieve the transfer of $\mathrm{NaCl}$ from the brine. In the case of Turhan et al. [1], using $40 \mathrm{~g}$ of anchovy fillets (Engraulis encrasicholus) and $10 \mathrm{~min}$ were sufficient for the samples treated with ultrasound $\left(30 \mathrm{~W} / \mathrm{cm}^{2}\right)$ to present higher transport of $\mathrm{NaCl}$ than those with static marinade. Ultrasonication does not equal the amount of salt in the cubes marinated by immersion (Figure 1a). However, the immersion marination (control) was carried out for $24 \mathrm{~h}$ at $4{ }^{\circ} \mathrm{C}$, while the HIU-assisted marination (ultrasound) was carried out for $20 \mathrm{~min}$ at $4{ }^{\circ} \mathrm{C}$, which seems enough time to almost equal the control in content of salt (\%). HIU-assisted marination dramatically shortens the time of traditional dip marinating meat. Subsequent studies should focus on increasing the marination time assisted by the HIU, seeking to make equal the salt content obtained in the immersion marination. 


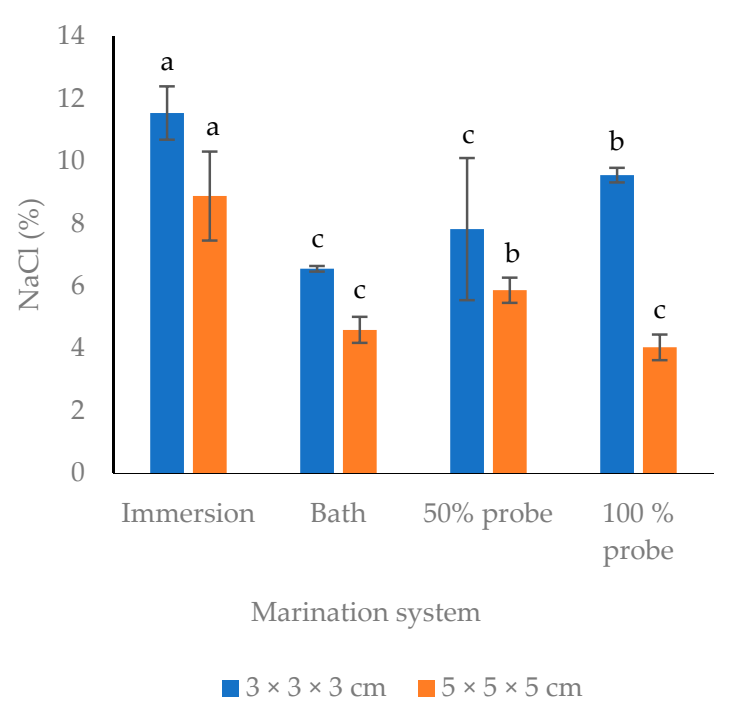

(a)

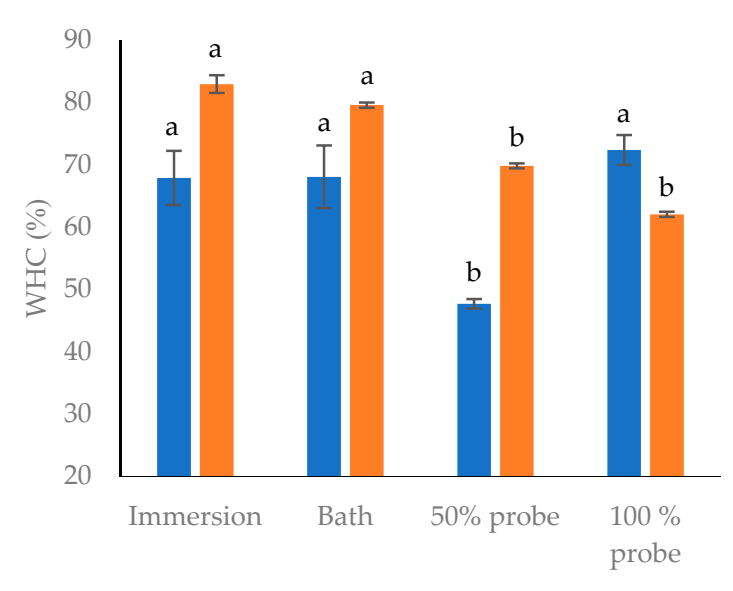

Marinade system

a $3 \times 3 \times 3 \mathrm{~cm} \quad \mathbf{m} \times 5 \times 5 \mathrm{~cm}$

(b)

Figure 1. Effect of the marination system and muscle size on sodium chloride content (a) and water holding capacity (WHC) (b) of pork leg stored for $7 \mathrm{~d}$ at $4{ }^{\circ} \mathrm{C}$. ${ }^{\mathrm{a}, \mathrm{b}, \mathrm{c}}$ Different letters indicate significant differences between treatments $(p<0.05)$.

Regarding the WHC in the muscle (Figure 1a), significant statistical differences were found between treatments $(p<0.0001)$. The results showed an inverse trend with the $\mathrm{NaCl}$ content; the samples with the highest WHC had the lowest content of $\mathrm{NaCl}\left(5 \mathrm{~cm}^{3}\right)$ and vice versa $\left(3 \mathrm{~cm}^{3}\right)$. The samples with the highest salt transfer experienced an apparent "dehydration", retaining less water. This is explained by the osmosis phenomenon, in which the salt solution (semiconcentrated) used in the brine (17\%) caused the dehydration of the meat. In this way, the $5 \mathrm{~cm}^{3}$ sample with low (5-8\%) NaCl content presented WHC values of $80 \%$ (immersion and ultrasonic bath treatments), while those $3 \mathrm{~cm}^{3}$ samples with $\mathrm{NaCl}$ contents between 10 and $12 \%$ presented a WHC of $70 \%$. Without doubt, this phenomenon is of great relevance in meat technology since a high WHC has a significant impact on performance and profits for the meat industry. Kang et al. [6] reported that ultrasound with a probe system (150 and $300 \mathrm{~W}$, $20 \mathrm{kHz}, 30$ and $120 \mathrm{~min}$ ), significantly increased WHC in Longissimus dorsi, due to polymerization caused by moderate oxidation of myosin. Their results were corroborated using electron microscopy studies, which allowed for the observation of swelling and interruption of myofibrils. They used $6 \% \mathrm{NaCl}$ in the brine $(6 \%)$ for $10 \mathrm{~mm}$ thick fillets. The same effects could have taken place in our study, where the $5 \mathrm{~cm}^{3}$ samples presented a high WHC compared to the $3 \mathrm{~cm}^{3}$ samples. The WHC of the $3 \mathrm{~cm}^{3}$ samples was reduced due to the high concentration of $\mathrm{NaCl}(10-12 \%)$ in the muscle, which might cause dehydration of the tissue. Stadnik, Dolatowski, and Baranowska [17] reported that the decrease of WHC in m. bovine Semimembranosus post mortem treated ( $24 \mathrm{~h}$ ) with ultrasound ( $2 \mathrm{~min}, 45 \mathrm{kHz}$ ) is due to the acceleration of the aging process (structural destruction of sarcomeres and fragmentation of myofibrils). A similar situation might have happened in our study, where the $5 \mathrm{~cm}^{3}$ samples treated with ultrasound probe system (50 and 100\%) showed a low WHC. However, McDonell et al. [12] found no effect of ultrasound application $\left(4.2,11\right.$, and $19 \mathrm{~W} / \mathrm{cm}^{2} ; 10,25$, or $\left.40 \mathrm{~min}\right)$ on the WHC of marinated bovine. They reported that salting with ultrasound produces a superficial phenomenon that can accelerate mass transfer and extract proteins, but denatures myosin when high power is used. Siró et al. [8] found that low frequency, low intensity ultrasound $\left(20 \mathrm{kHz}, 2-4 \mathrm{~W} / \mathrm{cm}^{2}\right)$ applied to NaCl-marinated porcine Longissimus dorsi (40 g/L), improved WHC when long times and high intensities were used. The effect was attributed to protein denaturation in the treated meat. 


\subsection{Weight and Weight Gain/Loss}

Significant differences $(p<0.0001)$ among treatments (immersion and/or ultrasound with a bath and probe system) were found in the weight of the $3 \mathrm{~cm}^{3}$ samples (Figure 2a), immediately after the marination after $7 \mathrm{~d}$ of storage at $4{ }^{\circ} \mathrm{C}$. The $3 \mathrm{~cm}^{3}$ samples treated with the $50 \%$ probe system showed the highest weight ( 43.71 and $39.92 \mathrm{~g}$, immediately after marination and after $7 \mathrm{~d}$ at $4{ }^{\circ} \mathrm{C}$, respectively), followed by HIU treatments ( $100 \%$ probe and bath). The samples marinated by immersion presented the lowest weights ( 32.49 and $30.3 \mathrm{~g}$, immediately after the marinade and after $7 \mathrm{~d}$ at $4{ }^{\circ} \mathrm{C}$, respectively). In general, the weight was maintained from the beginning of the marination process until the end of storage at $4{ }^{\circ} \mathrm{C}$. Different results were observed for the $5 \mathrm{~cm}^{3}$ samples (Figure 2b), where the weight was higher $(p<0.0001)$ in the samples treated by immersion $(159.44$ and $155.92 \mathrm{~g}$, immediately after marinating and after $7 \mathrm{~d}$ at $4{ }^{\circ} \mathrm{C}$, respectively). The other treatments presented similar weight values and they were constant during storage at $4{ }^{\circ} \mathrm{C}$.

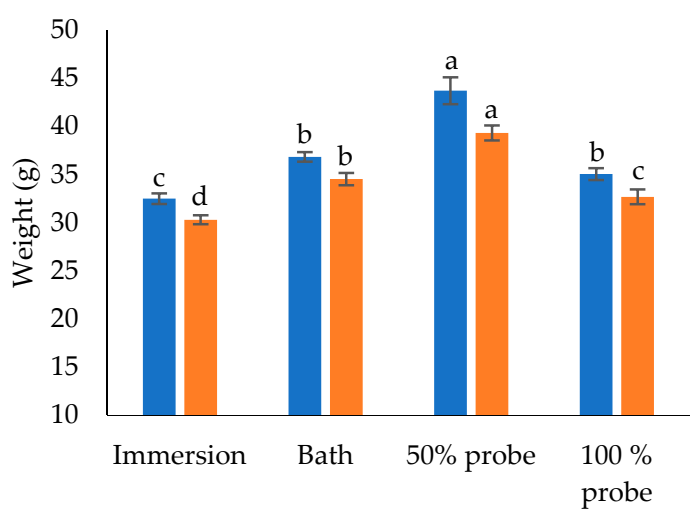

Marination system

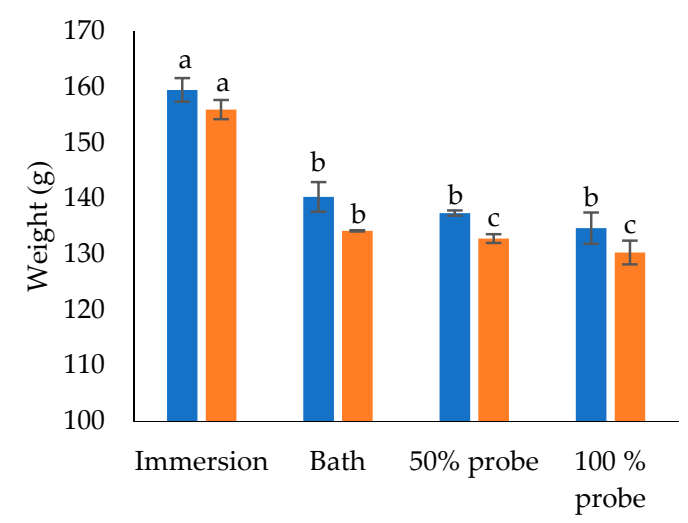

Marination system

- After marinade $\quad 7 \mathrm{~d} 4 \stackrel{\circ}{\circ} \mathrm{C}$
- After marinade $\quad \square \mathrm{d} 4 \stackrel{\circ}{\circ} \mathrm{C}$

(a)

(b)

Figure 2. Effect of the marination system on the weight of pork leg, immediately after marination and after $7 \mathrm{~d}$ storage at $4{ }^{\circ} \mathrm{C}$; muscle size of $3 \mathrm{~cm}^{3}(\mathbf{a})$ and $5 \mathrm{~cm}^{3}(\mathbf{b}) .{ }^{\mathrm{a}, \mathrm{b}, \mathrm{c}}$ Different letters indicate significant differences between treatments $(p<0.05)$.

Weight and WHC were affected differently in cubes. The $5 \mathrm{~cm}^{3}$ cubes retained more water than the $3 \mathrm{~cm}^{3}$ cubes, except in the $100 \%$ probe system. The WHC decreased only in the $100 \%$ probe system in the $3 \mathrm{~cm}^{3}$ cubes, while the WHC decreased significantly in the probe system (both 50 and 100\% amplitude) in the $5 \mathrm{~cm}^{3}$ cubes. The higher loss of water when using the probe system is possibly due to greater damage to the muscle structure, causing the breakdown of muscle fibers. In this regard, Chang et al. [18] reported that HIU-treated bovine Semitendinosus muscle had higher rates of water loss than controls. Stadnik et al. [17] also reported lower WHC in ultrasonicated meat compared to controls, attributing this effect to disruption in cell structure caused by ultrasound. A directly proportional relationship was not found between the WHC and the weight of the cubes. Both samples lost weight after $7 \mathrm{~d}$ storage at $4{ }^{\circ} \mathrm{C}$. However, it was expected that the highest weight in the $3 \mathrm{~cm}^{3}$ cubes (Figure 2a) was in traditionally marinated meat, and in a $100 \%$ probe system and bath-treated meat since they showed the highest WHC (Figure 1b). In contrast, the $3 \mathrm{~cm}^{3}$ samples with the highest weight were those treated in a 50\% probe system. This happened presumably because the samples with the highest WHC lost more water during the $7 \mathrm{~d}$ of storage at $4{ }^{\circ} \mathrm{C}$. Hence, subsequent studies should consider measuring the CRA immediately after treatment with $\mathrm{HIU}$, and every day during the process of storage at $4{ }^{\circ} \mathrm{C}$. Thus, weight constitutes a more objective measure because it expresses the real variation in weight during the marinating process (Figure $3 a, b)$. 

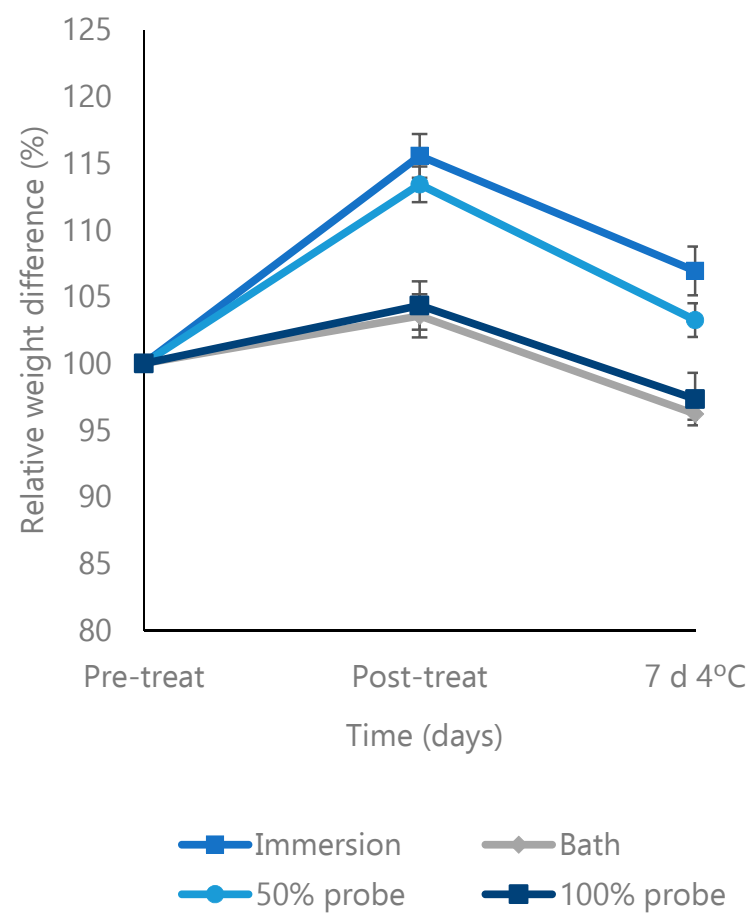

(a)
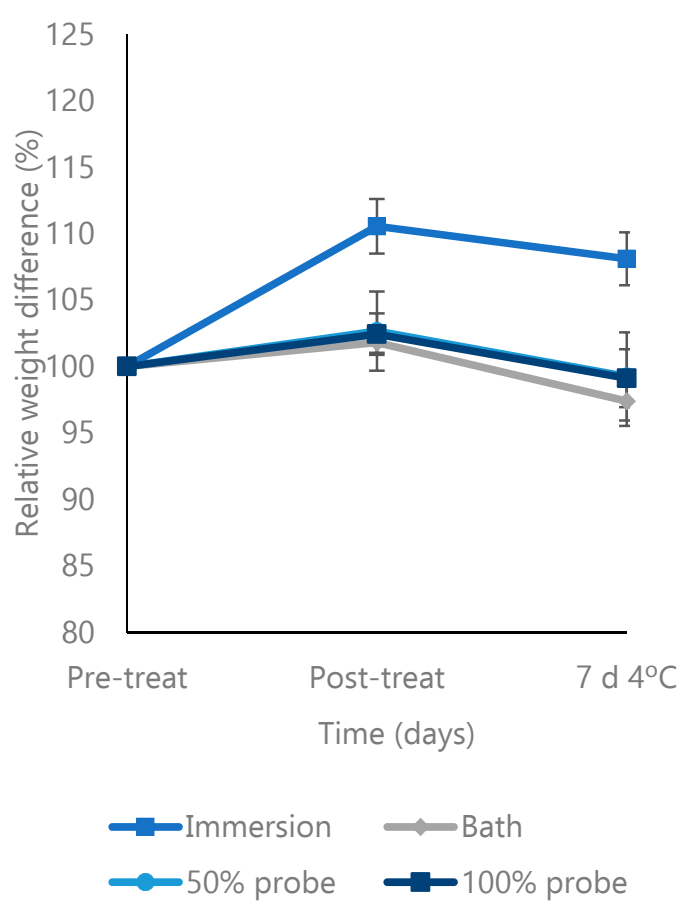

(b)

Figure 3. Behavior of the fresh weight (gain and/or loss) of pork leg during the marination process (pre-treat, post-treat and after $7 \mathrm{~d}$ storage at $4{ }^{\circ} \mathrm{C}$ ). Sample size of $3 \mathrm{~cm}^{3}$ (a) and $5 \mathrm{~cm}^{3}$ (b). Pre-treat $=$ before marination $\left(0 \mathrm{~h}\right.$ ) and post-treat = after marination (immersion for $24 \mathrm{~h}$ at $4{ }^{\circ} \mathrm{C}$; bath, $50 \%$ probe, and $100 \%$ probe for $20 \mathrm{~min}$ at $4{ }^{\circ} \mathrm{C}$ ).

The experimental units (experimental design) tend to have small variations. The meat samples ( 3 and $5 \mathrm{~cm}^{3}$ ) may present minimal differences in weight (Figure 3a,b, respectively). Therefore, the relative weight constitutes a more objective response variable than the water retention capacity, expressing the real variation of the fresh weight with respect to the initial weight of the muscle during the marinating process. Related to this, WHC measurements were made only after storage of $7 \mathrm{~d}$ at $4{ }^{\circ} \mathrm{C}$, so the results between WHC and weight differ markedly for the same treatment. To be comparable, both variables should be measured over time (before treatment, immediately after treatment, and during storage at $4{ }^{\circ} \mathrm{C}$ ). Figure 3 illustrates the relative weight (considered as $100 \%$ of the original weight of each treatment with its three repetitions) at different times of the marination process. The $3 \mathrm{~cm}^{3}$ samples treated with the $50 \%$ probe HIU system and those treated by immersion gained more fresh weight immediately after treatment (15-18\% of the original weight) and after storage at $7 \mathrm{~d}$ at $4{ }^{\circ} \mathrm{C}(6-7 \%$ of the initial weight). On the other hand, the $100 \%$ HIU-probe and bath treatments gained less weight during the marination process, so after $7 \mathrm{~d}$ at $4{ }^{\circ} \mathrm{C}$ they lost between $2-4 \%$ of the initial weight (Figure $3 a$ ). The $5 \mathrm{~cm}^{3}$ samples gained the most weight during the marinating process when treated by immersion, increasing the initial weight by up to $8 \%$ after $7 \mathrm{~d}$ at $4{ }^{\circ} \mathrm{C}$. Meanwhile, the other treatments lost between 1 and $3 \%$ of the initial weight after storage (Figure $3 b$ ). This indicates that the $5 \mathrm{~cm}^{3}$ samples should have been treated for a longer time during the HIU-assisted marinade. The $3 \mathrm{~cm}^{3}$ samples marinated with the $50 \%$ probe constitutes the ideal technology for salt transfer and weight gain during marination, since the results obtained are similar to those marinaded by immersion. This allows for a reduction in the process time from $24 \mathrm{~h}$ to $20 \mathrm{~min}$. Similarly, Chang et al. [18] reported beef samples $(2.5 \times 5 \times 5 \mathrm{~cm}$, $100 \mathrm{~g}$ of weight) treated for $30 \mathrm{~min}$ with ultrasound (ultrasonic processor, $40 \mathrm{kHz}, 1500 \mathrm{~W}$ ) with a significantly higher exudate than those sonicated for $20 \mathrm{~min}$. High pressures within the medium resulted in a higher amount of exudate and lower yield (lower weight). Regarding drip loss, they also reported that the samples treated with ultrasound showed higher rates of water loss. In addition, 
Stadnik et al. [17] documented that the WHC of ultrasound-treated bovine m. Semimenbranosus (2 min, $45 \mathrm{kHz}$ ) was lower than in controls, due to the disruption of cell structure. Smith [19] also marinated chicken breast fillets for 20 min using a brine based on $\mathrm{NaCl}$ and sodium tripolyphosphate (6 and 3\%, respectively). He reported that the ultrasound treatment reduced absorption, drip losses, and cooking performance. Controls (static marinade) presented higher absorption but higher drip loss (lower yield). His results differ from ours, since ultrasound treatments in both the 3 and $5 \mathrm{~cm}^{3}$ samples had less absorption than controls after storage at $4{ }^{\circ} \mathrm{C}$.

The main change is the mass transfer between meat and brine of salt and water together with small amounts of proteins and fat. When meat is exposed to brine, $\mathrm{NaCl}$ diffuses from brine to meat since the salt concentration in brine is higher than that in meat. The penetration of $\mathrm{NaCl}$ into meat may induce protein denaturation and solubilization [20]. Offer and Trinick [21] explained that most of the water in the muscle is held by capillary forces between the thick and thin filaments. They pointed out that the maximum retention of water by the myofibrils occurred under conditions when a considerable amount of the A-band proteins was extracted. Interfilament spacing determines the highest water-holding capacity of the myofibrils, and that spacing is primarily determined by long-range electrostatic forces. The functions that salt provides in meat mixtures are mainly determined by the dissociated ions $\mathrm{Na}^{+}$and $\mathrm{Cl}^{-}$. In the presence of salt, part of the insoluble myosin passes into the liquid phase and dissolves, increasing meat swelling and water holding capacity. The increased water-holding capacity of salt-treated meat gives it a higher cooking yield, and greater tenderness and juiciness when the product is consumed $[20,22,23]$.

\subsection{CIE (Commission Internationale d'Eclairage) $L^{*} a^{*} b^{*}$ Color}

The luminosity $\left(L^{*}\right)$ increased significantly $(p=0.0023)$ when the $3 \mathrm{~cm}^{3}$ samples were marinated by immersion and with a $50 \%$ probe system, while the redness $\left(\mathrm{a}^{*}\right)$ was negatively decreased $(p<0.0001)$ in both treatments (Table 1). From a commercial point of view, meat with a higher redness and high luminosity is more visually appealing to consumers. Therefore, HIU when using a probe with $50 \%$ amplitude as a marinade-assisted technology positively modifies the luminosity but negatively the value $\mathrm{a}^{*}$, while the opposite occurs in the bath system (positive effect in $\mathrm{a}^{*}$ but not in $\mathrm{L}^{*}$ ). These results were corroborated with the values obtained for hue and chroma, which combine the $L^{*} a^{*} b^{*}$ coordinates. The $3 \mathrm{~cm}^{3}$ samples marinated by immersion presented significantly higher values of hue $(p<0.0001)$, indicating a color closer to yellow (higher $\left.\mathrm{b}^{*}\right)$ than red. Hence, the bath system was the best when presenting a redder color than other treatments. Saturation expresses the attractiveness of the color, thus the immersion and bath treatments showed the best color as they were visually brighter.

Table 1. Effect of the marination system and sample size on color parameters $\mathrm{L}^{*}, \mathrm{a}^{*}, \mathrm{~b}^{*}$, hue angle $\left(\mathrm{H}^{\circ}\right)$, and $\mathrm{C}^{*}$ of pork leg stored for $7 \mathrm{~d}$ at $4{ }^{\circ} \mathrm{C}$.

\begin{tabular}{|c|c|c|c|c|c|}
\hline \multirow{2}{*}{$\begin{array}{c}\text { Treatment } \\
3 \mathrm{~cm}^{3} \text { Thick }\end{array}$} & \multicolumn{4}{|c|}{ Color } & \multirow[b]{2}{*}{$\mathrm{C}^{*}$} \\
\hline & $\mathbf{L}^{*}$ & $a^{*}$ & $b^{*}$ & $\mathbf{H}^{\circ}$ & \\
\hline Immersion & $51.3 \pm 0.6^{\mathrm{a}}$ & $3.3 \pm 0.2^{b}$ & $7.4 \pm 0.0^{\mathrm{a}}$ & $65.6 \pm 1.2^{\mathrm{a}}$ & $8.2 \pm 0.1^{a}$ \\
\hline HIU bath & $48.0 \pm 2.1^{b}$ & $5.9 \pm 0.4^{\mathrm{a}}$ & $5.0 \pm 0.4^{\mathrm{c}}$ & $40.4 \pm 4.3^{\mathrm{c}}$ & $7.7 \pm 0.2^{\mathrm{a}}$ \\
\hline Probe $50 \%$ & $48.5 \pm 0.7^{\mathrm{a}}$ & $2.1 \pm 0.0^{\mathrm{c}}$ & $5.7 \pm 0.1^{b}$ & $69.1 \pm 0.7^{\mathrm{a}}$ & $6.1 \pm 0.1^{\mathrm{c}}$ \\
\hline Probe $100 \%$ & $45.0 \pm 0.9^{b}$ & $3.6 \pm 0.5^{b}$ & $5.8 \pm 0.0^{b}$ & $58.2 \pm 3.4^{b}$ & $6.8 \pm 0.3^{b}$ \\
\hline $5 \mathrm{~cm}^{3}$ Thick & $\mathbf{L}^{*}$ & $a^{*}$ & $\mathbf{b}^{*}$ & $\mathbf{H}^{\circ}$ & $\mathrm{C}^{*}$ \\
\hline Immersion & $49.4 \pm 1.9^{a}$ & $2.5 \pm 0.3^{b}$ & $6.2 \pm 0.1^{a}$ & $67.6 \pm 3.1^{b}$ & $6.7 \pm 0.0^{a}$ \\
\hline HIU bath & $49.8 \pm 1.4^{\mathrm{a}}$ & $1.3 \pm 0.2^{c}$ & $5.1 \pm 0.3^{b}$ & $75.1 \pm 2.7^{\mathrm{a}}$ & $5.3 \pm 0.2^{b}$ \\
\hline Probe $50 \%$ & $46.1 \pm 1.5^{\mathrm{a}}$ & $3.3 \pm 0.4^{b}$ & $4.0 \pm 0.1^{\mathrm{c}}$ & $50.4 \pm 3.9^{c}$ & $5.2 \pm 0.3^{b}$ \\
\hline Probe $100 \%$ & $46.1 \pm 0.9^{\mathrm{a}}$ & $5.5 \pm 0.3^{a}$ & $4.9 \pm 0.2^{b}$ & $42.0 \pm 0.3^{d}$ & $7.4 \pm 0.4^{\mathrm{a}}$ \\
\hline
\end{tabular}

$\mathrm{a}, \overline{\mathrm{b}, \mathrm{c}}$ Different letters within the same row indicate significant differences between treatments $(p<0.05)$. 
In the $5 \mathrm{~cm}^{3}$ samples, significant differences were found in $\mathrm{a}^{*}$ and $\mathrm{b}^{*}$ but not in $\mathrm{L}^{*}(p<0.0001$, $p<0.0001$, and $p=0.0266$, respectively). In this case, the $100 \%$ probe system was the best with the highest redness, which could be corroborated by the smallest hue angle (red tones). The immersion system and $50 \%$ probe treatments presented lower redness and higher hue angle, indicating a higher tendency towards yellow tones. Regarding saturation, significant differences were also found $(p<0.0001)$. Based on these findings, the best treatments for having brighter and less opaque meat were the immersion treatment and $100 \%$ probe marination treatment. Therefore, HIU as a technology to assist in marinating positively modifies $\mathrm{a}^{*}, \mathrm{C}^{*}$ (saturation), and the hue angle in the $5 \mathrm{~cm}^{3}$ samples when using a $100 \%$ probe system. Meanwhile, the bath system negatively modifies $\mathrm{a}^{*}, \mathrm{~b}^{*}, \mathrm{C}^{*}$, and the hue angle for the same sample size. Similar results were reported by Gómez-Salazar et al. [24], who found significant differences in $\mathrm{L}^{*}, \mathrm{a}^{*}$, and $\mathrm{b}^{*}$ in rabbit meat due to the effect of ultrasound-assisted marination. They observed increases in $\mathrm{L}^{*}, \mathrm{a}^{*}$, and $\mathrm{b}^{*}$ in sonicated samples, regardless of salt concentration. In the present study, $\mathrm{L}^{*}, \mathrm{a}^{*}$, and $\mathrm{b}^{*}$ were dependent on the ultrasonic system used and the size of the muscle. Hence, the highest $L^{*}$ and $a^{*}$ values were obtained for both sonicated samples and controls without US (immersion), due to divergence in treatment time. The effects that ultrasound has on the $\mathrm{L}^{*}, \mathrm{a}^{*}$ and $\mathrm{b}^{*}$ color parameters differ between studies due to the variability in the experimental conditions during the ultrasound treatment. Chang et al. [25] found no significant differences in the $L^{*}$ and $a^{*}$ values in bovine $\mathrm{m}$. Semitendinosus. However, the $\mathrm{b}^{*}$ value was significantly modified due to the effect of the exposure time to ultrasound. Conversely, Jayasooriya et al. [10] did not report modifications in $\mathrm{L}^{*}, \mathrm{a}^{*}$, or $\mathrm{b}^{*}$ parameters in $\mathrm{m}$. Semiteninosus and Longissimus lumborum et thoracis, due to the effect of ultrasound application. This difference between both studies may be explained by the experimental sample size. In the study by Jayasooriya et al. [10], samples were $4 \times 6 \times 2 \mathrm{~cm}$, and ultrasonication applied for short times $(0.5-4 \mathrm{~min})$. Thus, the cavitation phenomenon was probably not enough to cause significant changes in muscle color, despite the ultrasonication performed at $15-30{ }^{\circ} \mathrm{C}$. In contrast, in the study of Chang et al. [25] smaller muscles $(2.5 \times 5 \times 5 \mathrm{~cm})$ and long times $(10-60 \mathrm{~min})$ of ultrasound were used. In the present study, the same trend was observed. The $5 \mathrm{~cm}^{3}$ samples did not show significant differences in $L^{*}$ due to the effect of the ultrasound system. Nevertheless, the $3 \mathrm{~cm}^{3}$ samples presented significant differences in $\mathrm{L}^{*}, \mathrm{a}^{*}$, and $\mathrm{b}^{*}$. Pohlman et al. [26] reported unfavorable changes in color in $24 \mathrm{~h}$ post mortem ultrasound-treated bovine pectoral muscle, during storage. Muscles became darker, less red, and more orange, due to the denaturation of myoglobin by the effect of temperature during the ultrasound process. These results are quite close to those obtained in the present investigation for the $3 \mathrm{~cm}^{3}$ samples in the $50 \%$ probe system, and in $5 \mathrm{~cm}^{3}$ samples for the bath system, where the high values of hue indicate red tones with a tendency towards yellow (orange). Changes in color have been attributed to changes in the secondary structure of proteins due to oxidation during curing processing. In this regard, Kang et al. [7] reported a significant increase in carbonyl contents and a decrease in total thiol groups and protein aggregation.

In practice it is difficult for CIEL $\mathrm{a}^{*} \mathrm{~b}^{*}$ color coordinates to be positively affected when applying the ultrasound technology. Thus, HIU positively modifies certain color parameters and at the same time, negatively affecting others. For the $3 \mathrm{~cm}^{3}$ samples, the $50 \%$ probe system produced higher weight and salt transfer during the marinade process. However, $\mathrm{L}^{*}$ was positively affected, but $\mathrm{a}^{*}$ and the hue angle were negatively affected. In contrast, the bath system had the best color characteristics (higher $\mathrm{a}^{*}$, hue, and saturation), but the salt transfer and weight gain were relatively low. In the case of the $5 \mathrm{~cm}^{3}$ samples, the salt transfer and the weight gain were low, so the positive effects in $\mathrm{a}^{*}$ and hue with the probe system (both 50 and 100\%) are not conclusive to recommend the use of HIU as a technology to assist marinade. Nonetheless, the results can be considered as a guideline that can be used to recommend an increase in the process times, in order to achieve high and homogeneous profiles in salts transfers and an increase in weight gain. 


\subsection{Microbiological Counts}

No significant differences $(p=0.374)$ were found among treatments in the mesophilic bacteria counts in the $3 \mathrm{~cm}^{3}$ samples. Whereas, in the $5 \mathrm{~cm}^{3}$ samples the trend was different, the $50 \%$ probe treatment had the highest bacterial counts $\left(6.35 \log _{10} \mathrm{CFU} / \mathrm{mL}\right)$, while the other ultrasound treatments showed a significant $(p=0.0016)$ mesophilic log reduction $\left(0.61 \log _{10}\right)$. The studies evaluating the effect of ultrasound on meat are not conclusive. While Haughton et al. [27] found no significant decrease in the total viable count of ultrasound-treated chicken thighs, Dolatowski and Stasiak [28] reported a significant decrease in mesophilic bacteria counts in fresh chicken meat. Similar results to ours were observed by Piñon et al. [29] and Carrillo-López et al. [30], who reported an increase in mesophilic bacteria counts after $7 \mathrm{~d}$ of storage at $4{ }^{\circ} \mathrm{C}$ in chicken breasts and bovine Longissimus dorsi treated with ultrasound, respectively. Joyce et al. [31] found that frequencies of 20 and $40 \mathrm{kHz}$ decrease viable cells and increase dead cells of Escherichia coli and Klebsiella pneumonia. Instead, high frequencies $(580 \mathrm{kHz})$ deagglomerate groups of bacteria without causing disruption of the cellular membrane. Sonication had two effects on bacteria: inactivation and deagglomeration, depending on intensity and frequency. The mesophilic bacteria determined in this study correspond to the total aerobic count, which is a heterogeneous flora in the food, and therefore, the effect of the ultrasound treatment depends on the susceptible and/or resistant microorganisms. This explains that the ultrasound treatment was not effective in the control of mesophilic bacteria in the $3 \mathrm{~cm}^{3}$ samples, whereas in $5 \mathrm{~cm}^{3}$ samples, the counts of this group of bacteria increased. These observations suggest that HIU treatment produced the extraction of food components that could be used by mesophilic bacteria, contributing to their multiplication during storage [32,33]. It is well known that the sensitivity of bacteria to ultrasonic waves also depends on the structural differences between microorganisms. So, Gram-negative bacteria have a double lipid cell membrane (one external and one cytoplasmic) with a thin layer of peptidoglycan among them, making them more susceptible to ultrasound treatment. Meanwhile, Gram-positive cells have a single lipid membrane with a thicker peptidoglycan wall, making them more resistant to ultrasonic waves [34].

The $100 \%$ probe marination treatment significantly increased $(p=0.002)$ the psychrophilic bacteria in the $3 \mathrm{~cm}^{3}$ samples, while in the other treatments the counts decreased significantly by approximately $2 \log _{10}$ (Figure 4a). In the $5 \mathrm{~cm}^{3}$ samples, immersion marination completely reduced the counts of psychrophilic bacteria $(p<0.0001)$. In HIU-assisted marination treatments, the counts of this bacteria were relatively high, particularly in the $50 \%$ probe system, which presented $10.42 \log _{10} \mathrm{CFU} / \mathrm{mL}$ after $7 \mathrm{~d}$ of storage at $4{ }^{\circ} \mathrm{C}$. These results are similar to those obtained by Carrillo-Lopez et al. [30], who reported significant increases in counts of psychrophilic bacteria in Longissimus dorsi treated with ultrasound after $7 \mathrm{~d}$ of storage at $4{ }^{\circ} \mathrm{C}$, with intensities of 16 and $90 \mathrm{~W} / \mathrm{cm}^{2}$. In contrast, Caraveo et al. [35] observed a significant decrease in psychrophilic bacteria after $10 \mathrm{~d}$ of storage in bovine Semitendinosus treated with ultrasound. The increase in the count of this group of bacteria is due to the storage of meat, since this group of microorganisms grows under refrigerated conditions. Similarly, Piñon et al. [29] observed a significant decrease in psychrophilic bacteria from chicken meat immediately after ultrasound treatment. However, the counts increased significantly after storage for $7 \mathrm{~d}$.

No CFU of psychrophilic bacteria were found in the marinated samples in the immersion system (Figure $4 \mathrm{~b}$ ) after storage for $7 \mathrm{~d}$ at $4{ }^{\circ} \mathrm{C}$. Psychrophilic bacteria grow at refrigeration temperatures and samples were stored at those temperatures. We hypothesized that the ultrasonication made the nutrients more available to the bacteria after cell disruption. Hence, HIU-treated meat resulted with higher contents of psychrophilic bacteria. Sams and Feria [36] suggested that when meat is subjected to cavitation, there is release of nutrients. In addition, Pitt and Ross [37] reported that ultrasound can increase the rate of oxygen and nutrient transport in bacterial cells, which improves their growth. Another hypothesis is that salt may increase the water holding capacity in the controls $\left(3 \mathrm{~cm}^{3}\right.$ cubes), making water less available to bacteria during storage. In this regard, Jeong et al. [38] reported that 
marination of pork ham, stored at $4{ }^{\circ} \mathrm{C}$, completely inhibited the growth of viable microorganisms and coliforms.

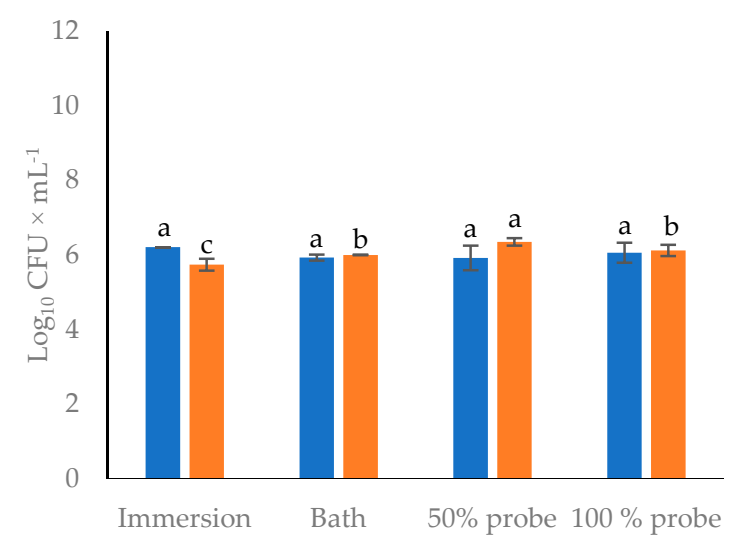

Marination system - $3 \times 3 \times 3 \mathrm{~cm} \quad \mathbf{m} \times 5 \times 5 \mathrm{~cm}$

(a)

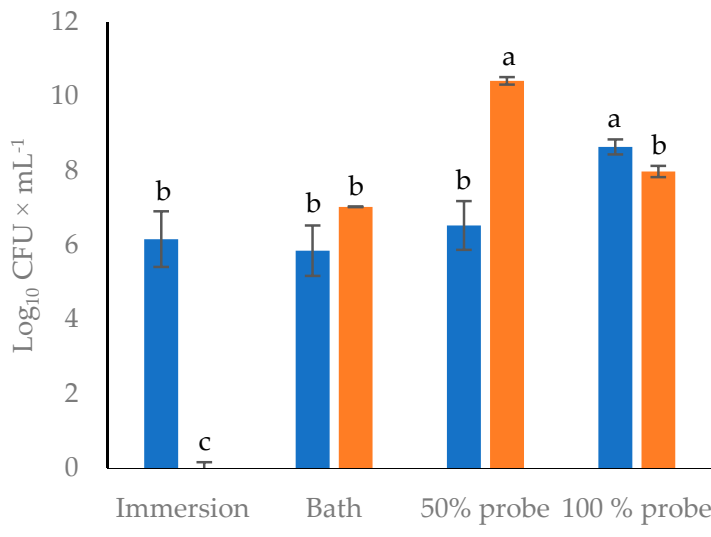

Marination system a $3 \times 3 \times 3 \mathrm{~cm} \quad 5 \times 5 \times 5 \mathrm{~cm}$

(b)

Figure 4. Effect of the marination system and muscle size on the count of mesophilic (a) and psychrophilic bacteria (b) of pork leg stored for $7 \mathrm{~d}$ at $4{ }^{\circ} \mathrm{C}$. ${ }^{\mathrm{a}, \mathrm{b}, \mathrm{c}}$ Different letters indicate significant differences between treatments $(p<0.05)$.

Coliform bacteria increased significantly in the HIU-assisted marination treatments (Figure 5a), in samples of $3 \mathrm{~cm}^{3}$ and $5 \mathrm{~cm}^{3}$ ( $p=0.002$ and $p=0.0003$, respectively). The $50 \%$ immersion and probe treatments showed the lowest counts of coliform bacteria (4.18 and $4.29 \log _{10} \mathrm{CFU} / \mathrm{mL}$, respectively) in the $3 \mathrm{~cm}^{3}$ samples. In the $100 \%$ probe system, the counts of this group of bacteria increased to $6.6 \log _{10}$. In $5 \mathrm{~cm}^{3}$ samples, immersion marination reduced coliform bacteria in the muscle up to four logarithmic units (from $5-5.83$ to $0.9 \log _{10}$ ). Therefore, HIU as an aid technology to marinate is not an appropriate method for control of this group of bacteria. The coliform group is an indicator of fecal matter; however, it is also an indicator of poor sanitary practices in foods that have received heat treatment [39]. Contrary to this study, Carrillo-Lopez et al. [30] and Caraveo et al. Paniwyk [35] observed a significant decrease in coliform bacteria counts in bovine Longissimus dorsi and Semitendinosus muscles treated with ultrasound after 7 and $10 \mathrm{~d}$ of storage at $4{ }^{\circ} \mathrm{C}$, respectively. Haughton et al. [27] reported nonviable enterobacteria in chicken skin treated with an HIU probe, while low intensity sonication in a bath system did not reduce the Enterobacteriaceae family that the genera of the coliform group belongs to. When curing beef in liquid brine, Kang et al. [40] found that a time of 120 min was the optimal ultrasound treatment for the reduction of Escherichia coli O157:H7. A coliform pathogen, E. coli O157:H7 produces hemorrhagic colitis due to the consumption of uncooked or undercooked meat. The production of hydrogen peroxide in brine during ultrasound causes microbial inactivation during the curing process, which results in the formation of cell fragments by destroying the integrity of the cell membrane. Longer times of ultrasonication should produce a decrease in coliform bacteria in pork, under the experimental conditions of this research. Piñon et al. [33] also found no significant reductions in chicken meat Escherichia coli counts due to the effect of the ultrasound time (30 and $50 \mathrm{~min}$ ) or type of packaging (aerobic and anaerobic), neither before the ultrasound treatment, nor after $7 \mathrm{~d}$ of storage at $4{ }^{\circ} \mathrm{C}$. 


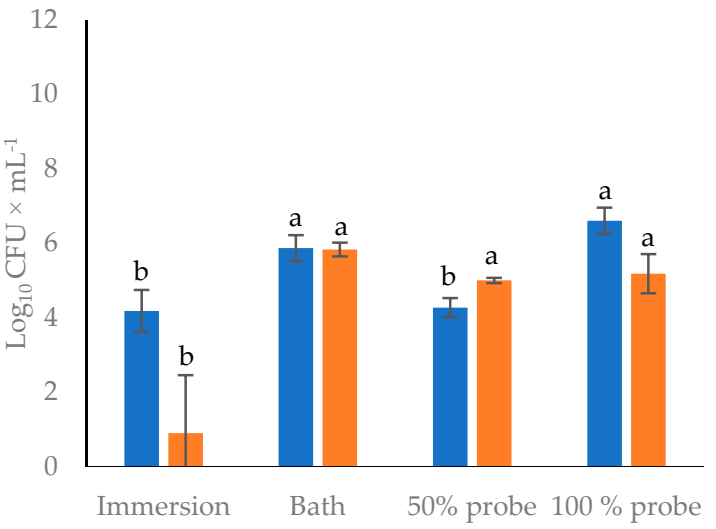

Marination system

- $3 \times 3 \times 3 \mathrm{~cm} \quad 5 \times 5 \times 5 \mathrm{~cm}$

(a)

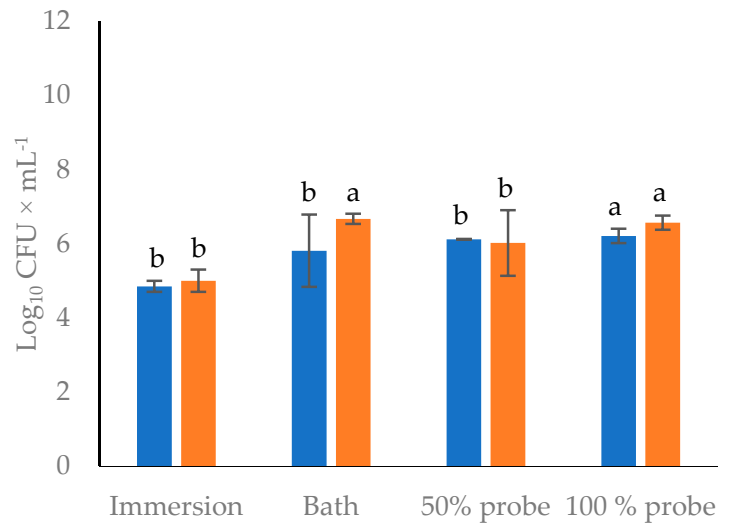

Marination system

$\mathbf{\square} 3 \times 3 \times 3 \mathrm{~cm} \quad 5 \times 5 \times 5 \mathrm{~cm}$

(b)

Figure 5. Effect of the marination system and muscle size on the count of coliform (a) and acid lactic bacteria (b) of pork leg stored for $7 \mathrm{~d}$ at $4{ }^{\circ} \mathrm{C}$. ${ }^{\mathrm{a}, \mathrm{b}, \mathrm{c}}$ Different letters indicate significant differences between treatments $(p<0.05)$.

Regarding lactic acid bacteria (Figure $5 \mathrm{~b}$ ), only the $100 \%$ probe system significantly increased ( $p=0.0372$ ) the counts in the $3 \mathrm{~cm}^{3}$ samples. The other treatments, however, presented equal counts. The $50 \%$ probe and dip marination treatments significantly reduced LAB counts $(p=0.01)$ in the $5 \mathrm{~cm}^{3}$ cubes. The $100 \%$ probe and ultrasonic bath systems were not efficient for the control of LAB. According to Piñon et al. [33], $7 \mathrm{~d}$ storage at $4{ }^{\circ} \mathrm{C}$ significantly increases LAB counts in chicken meat treated with ultrasound. Further, the ultrasonication time (30 and $50 \mathrm{~min}$ ) and the type of packaging (aerobic and anaerobic) have no effect on reducing LAB. These results are similar to the present study. HIU applied to pork (probe or bath) did not reduce LAB counts, compared to the traditional marination by immersion. The significant increase in LAB counts in the $3 \mathrm{~cm}^{3}$ sample treated with a probe system (10\% amplitude), and in the $5 \mathrm{~cm}^{3}$ sample treated with a bath and probe system (100\% amplitude) during storage at $4{ }^{\circ} \mathrm{C}$, can be positive since LAB produces antimicrobial compounds that preserve food during refrigeration. In this regard, Díaz-Ruíz et al. [41] reported that the strain EC52 of Lactobacillus plantarum reduces the levels of Listeria monocytogenes, and inhibits the proliferation of Escherichia coli. Hence LABs can be added as a protective culture in meat mixtures to make fermented sausages. LABs are well known for their ability to produce inhibitors and metabolic end products, such as organic acids, reuterin, reutericycline, antifungal peptides, and bacteriocins. The significant increase in LAB counts may be due to the extraction and release of nutrients and water from food [32], as occurs in the development of starter cultures (LAB) in dairy products such as yogurt [42].

\section{Conclusions}

$\mathrm{NaCl}$ content is significantly affected by the marination system and sample size. In the smallest samples $\left(3 \mathrm{~cm}^{3}\right)$ salt transfer was higher compared to $5 \mathrm{~cm}^{3}$ samples. Although the probe system was very efficient in the transfer of salt, the immersion marination system was the most efficient in both $3 \mathrm{~cm}^{3}$ and $5 \mathrm{~cm}^{3}$ samples due to the long process time $(24 \mathrm{~h})$. The WHC had an inverse trend with the $\mathrm{NaCl}$ content, so the cubes with higher salt transfer experienced dehydration, retaining less water. The relative weight constitutes a more objective response variable than WHC, expressing the real variation of the final weight with initial weight of the muscle during the marinating process. The $3 \mathrm{~cm}^{3}$ sample treated by immersion and in a $50 \%$ probe system gained more weight (in relation to the initial weight, 7.45 and $6.64 \%$, respectively) after $7 \mathrm{~d}$ at $4{ }^{\circ} \mathrm{C}$, meanwhile the $5 \mathrm{~cm}^{3}$ sample 
marinated by immersion gained $8.1 \%$. There were weight losses in the other treatments. Color parameters in immersion were negatively affected, obtaining orange color after storage for $7 \mathrm{~d}$ at $4{ }^{\circ} \mathrm{C}$. The probe system produced redder and brighter color of meat. The probe system with amplitudes of $100 \%$ significantly reduced the counts of mesophilic and psychrophilic bacteria in cubes of the $5 \mathrm{~cm}^{3}$ sample. However, HIU cannot be considered as an efficient decontamination technology during storage. A significant increase $(p<0.05)$ in lactic acid bacteria counts in ultrasonicated meat by the probe system with $100 \%$ amplitude may bring benefits for meat preservation during storage. The use of HIU as a technology to assist meat marination must consider muscle size as a control parameter, before scaling it up, since the ultrasonic system significantly affects quality variables depending on sample size.

This study contributes to the knowledge of the effects of HIU application on cured pork. Results continue to be very variable among studies. Therefore, to extrapolate laboratory experiments on an industrial scale needs to take into account the factors related to the production of a large volume of materials, and to design and develop equipment with the ultrasound requirements related to power, intensity, and amplitude.

Author Contributions: L.M.C.-L. conceived and designed the experiments; B.Y.C.-G. and M.H.-J. performed the experiments; L.M.C.-L. analyzed the data; I.A.G.-G. and A.D.A.-R. contributed reagents/materials/analysis tools. All authors discussed the results and contributed to the final manuscripts. All authors have read and agreed to the published version of the manuscript.

Funding: This research was funded by the Mexican Council of Science and Technology (CONACyT) under the program PDCPN 2015-Project 186.

Conflicts of Interest: The authors declare no conflict of interest.

\section{References}

1. Turhan, S.F.; Saricaoglu, F.; Oz, F. The effect of ultrasonic marinating on the transport of acetic acid and salt in anchovy marinades. Food Sci. Technol. Res. 2013, 19, 849-853. [CrossRef]

2. Yusop, S.M.; O'Sullivan, J.P.; Kerry, J.P. Marinating and enhancement of the nutritional content of processed meat products processed meats. In Processed Meats: Improving Safety, Nutrition and Quality, 1st ed.; Kerry, J.P., Kerry, J.F., Eds.; Woodhead Publishing: Cornwall, UK, 2011; Volume 1, pp. 421-449.

3. Inguglia, E.S.; Burgess, J.P.; Kerry, J.P.; Tiwari, B.K. Ultrasound-assisted marination: Role of frequencies and treatment time on the quality of sodium-reduced poultry meat. Foods 2019, 8, 473. [CrossRef] [PubMed]

4. Gonzalez-Gonzalez, L.; Luna-Rodriguez, L.; Carrillo-Lopez, L.M.; Alarcon-Rojo, A.D.; Garcia-Galicia, I.A.; Reyes-Villagrana, R. Ultrasound as an alternative to conventional marination: Acceptability and mass transfer. J. Food Qual. 2017, 2017, ID 8675720. [CrossRef]

5. Carcel, J.A.; Benedito, J.; Bon, J.; Mulet, A. High intensity ultrasound effects on meat brining. Meat Sci. 2007, 76, 611-619. [CrossRef]

6. Kang, D.; Wang, A.; Zhou, G.; Zhang, W.; Xu, S.; Guo, G. Power ultrasonic on mass transport of beef: Effects of ultrasound intensity and $\mathrm{NaCl}$ concentration. Innov. Food Sci. Emerg. Technol. 2016, 35, 36-44. [CrossRef]

7. Kang, D.; Zou, Y.H.; Cheng, Y.P.; Xing, L.J.; Zhou, G.H.; Zhang, W.G. Effects of power ultrasound on oxidation and structure of beef proteins during curing processing. Ultrason. Sonochem. 2016, 33, 47-53. [CrossRef]

8. Siró, I.; Vén, C.; Balla, C.; Jonás, G.; Zeke, I.; Friedrich, L. Application of an ultrasonic assisted curing technique for improving the difussion of sodium chloride in porcine meat. J. Food Eng. 2009, 91, 353-362. [CrossRef]

9. Alarcon-Rojo, A.D.; Janacua, H.; Rodrigez, J.C.; Paniwnyk, L.; Mason, T.J. Power ultrasound in meat processing. Meat Sci. 2015, 107, 86-93. [CrossRef]

10. Jayasooriya, S.D.; Torley, P.J.; D'Arcy, B.R.; Bhandari, B.R. Effect of high power ultrasound and ageing on the physical properties of bovine semitendinosus and longissimus muscles. Meat Sci. 2007, 75, 628-639. [CrossRef]

11. Mcdonell, C.K.; Lyng, J.G.; Arimi, J.M.; Allen, P. The acceleration pf bovine curing by power ultrasound: A pilot-scale production. Innov. Food Sci. Emerg. Technol. 2014, 26, 191-198. [CrossRef] 
12. Mcdonell, C.K.; Allen, P.; Morin, C.; Lyng, J.G. The effect of ultrasonic salting on protein and water-protein interactions in meat. Food Chem. 2014, 15, 245-251. [CrossRef] [PubMed]

13. Nielsen, S. Food Analysis Laboratory Manual, 1st ed.; Springer: Indianapolis, IN, USA, 2015; pp. $79-85$.

14. Tsai, T.; Ockerman, H. Water binding measurement of meat. J. Food Sci. 1981, 46, 697-701. [CrossRef]

15. American Meat Science Association. Meat Colour Measurement Guidelines, 1st ed.; Springer: Chicago, IL, USA, 2012; pp. 45-52.

16. Feng, P.; Weagant, S.D.; Grant, M.A. Enumeration of Escherichia coli and the coliform bacteria. In Bacteriological Analytical Manual (BAM), 8th ed.; Food and Drug Administration: White Oak, MD, USA, 1998. Available online: https://www.fda.gov/food/laboratory-methods-food/bacteriological-analytical-manualbam (accessed on 14 August 2019).

17. Stadnik, J.; Dolatowski, Z.J.; Baranowska, H.M. Effects of ultrasound treatment on water holding properties and microstructure of beef (m. Semimembranosus) during ageing. LWT Food Sci. Technol. 2008, 10, 2151-2158. [CrossRef]

18. Chang, H.-J.; Wang, Q.; Tang, C.-H.; Zhou, G.-H. Effects of ultrasound treatment on connective tissue collagen and meat quality of beef Semitendinosus muscle. J. Food Qual. 2015, 38, 256-267. [CrossRef]

19. Smith, D.P. Effect of ultrasonic marination on broiler breast meat quality and Salmonella contamination. Int. J. Poult. Sci. 2011, 10, 757-759. [CrossRef]

20. Desmond, E. Reducing salt: A challenge for the meat industry. Meat Sci. 2006, 74, 188-196. [CrossRef]

21. Offer, G.; Trinick, J. On the mechanism of water holding in meat: The swelling and shrinking of myofibrils. Meat Sci. 1983, 8, 245-281. [CrossRef]

22. Gregory, N.G. Animal Welfare and Meat Science, 1st ed.; CABO Publishing: Littleton, CO, USA, 1998; pp. 108-122.

23. Tarté, R. Ingredients in Meat Products, 1st ed.; Springer: New York, NY, USA, 2009; pp. 1-23.

24. Gómez-Salazar, J.A.; Ochoa-Montes, D.A.; Cerón-García, A.; Ozuna, C.; Sosa-Morales, M.E. Effect of Acid marination assisted by power ultrasound on the quality of rabbit meat. J. Food Qual. 2018, 2018, 5754930. [CrossRef]

25. Chang, H.-J.; Xu, X.-L.; Zhou, G.-H.; Li, C.B.; Huang, M. Effects of characteristics changes of collagen on meat physicochemical properties of beef Semitendinosus muscle during ultrasonic processing. Food Bioprocess Technol. 2012, 5, 285-297. [CrossRef]

26. Pohlman, F.W.; Dikeman, M.E.; Kropf, D.H. Effects of high intensity ultrasound treatment, storage time and cooking method on shear, sensory, instrumental color and cooking properties of packaged and unpackaged beef pectoralis muscle. Meat Sci. 1997, 46, 89-100. [CrossRef]

27. Haughton, P.N.; Lyng, J.G.; Morgan, D.J.; Cronin, D.; Noci, F.; Fanning, S.; Whyte, P. An evaluation of the potential of high-intensity ultrasound for improving the microbial safety of poultry. Food Bioprocess Technol. 2012, 5, 992-998. [CrossRef]

28. Dolatowski, Z.; Stasiak, D. Bacterial contamination of meat and meat products after ultrasound treatment. Acta Sci. Pol. Technol. Aliment. 2002, 1, 55-65.

29. Piñon, M.; Paniwnyk, L.; Alarcon-Rojo, A.; Renteria, A.; Nevarez, V.; Janacua-Vidales, H.; Mason, T. Power ultrasound effect on poultry meat microbial flora. In Proceedings of the 13th Meeting of the European Society of Sonochemistry, Lvivi, Ikraine, 1-5 July 2012; pp. 182-183.

30. Carrillo-Lopez, L.M.; Huerta-Jimenez, M.; Garcia-Galicia, I.A.; Alarcon-Rojo, A.D. Bacterial control and structural and physicochemical modification of bovine Longissimus dorsi by ultrasound. Ultrason. Sonochem. 2019, 58, 104608. [CrossRef] [PubMed]

31. Joyce, E.; Al-Hashimi, A.; Mason, T.J. Assessing the effect of different ultrasonic frequencies on bacterial viability using flow cytometry. J. Appl. Microbiol. 2011, 110, 862-870. [CrossRef]

32. Vilkhu, K.; Mawson, R.; Simons, L.; Bates, D. Applications and opportunities for ultrasound assisted extraction in the food industry-A review. Innov. Food Sci. Emerg. Technol. 2008, 9, 161-169. [CrossRef]

33. Piñon, M.I.; Alarcon-Rojo, A.D.; Renteria, A.L.; Carrillo-Lopez, L.M. Microbiological properties of poultry breast meat treated with high-intensity ultrasound. Ultrasonics 2020, 102, 105680. [CrossRef]

34. Piyasena, P.; Mohareb, E.; Mckellar, R.C. Inactivation of microbes using ultrasound: A review. J. Sci. Food Agric. 2015, 95, 2487-2493. [CrossRef] 
35. Caraveo, O.; Alarcon-Rojo, A.D.; Renteria, A.; Santellano, E.; Paniwnyk, L. Physicochemical and microbiological characteristics of beef treated with high-intensity ultrasound and stored at $4{ }^{\circ} \mathrm{C}$. Int. J. Food Microbiol. 2003, 87, 207-216. [CrossRef]

36. Sams, A.R.; Feria, R. Microbial effects of ultrasonication of broiler drumstick skin. J. Food Sci. 1991, 56, 247-248. [CrossRef]

37. Pitt, W.G.; Ross, S.A. Ultrasound increases the rate of bacterial cell growth. Biotechnol. Prog. 2003, 19, 1038-1044. [CrossRef]

38. Jeong, K.; Hyeonbin, O.; Shin, S.Y.; Young-Soon, K. Effects of different marination conditions on quality, microbiological properties, and sensory characteristics of pork ham cooked by the sous-vide method. Korean J. Food Sci. Anim. Resour. 2018, 38, 506514.

39. Kornacki, J.L.; Gurtler, J.B.; Stawick, B.A. Enterobacteriaceae, Coliforms, and Escherichia coli as quality and safety indicators. In Compendium of Methods for the Microbiological Examination of Foods, 5th ed.; Salfinger, Y., Tortorello, M.L., Eds.; American Public Health Association: Washington, WA, USA, 2013; Volume 1.

40. Kang, D.; Jiang, Y.; Xing, L.; Zhou, G.; Zhang, W. Inactivation of Escherichia coli O157:H7 and Bacillus cereus by power ultrasound during the curing processing in brining liquid and beef. Food Res. Int. 2017, 102, 717-727. [CrossRef] [PubMed]

41. Díaz-Ruiz, G.; Ben, N.; Abriouel, H.; Martínez-Cañamero, M.; Gálvez, A. Inhibition of Listeria monocytogenes and Escherichia coli by bacteriocin-producing Lactobacillus plantarum ec52 in a meat sausage model system. Afr. J. Microbiol. Res. 2012, 6, 1103-1108.

42. Mason, T.J.; Lorimer, J.P. Applied Sonochemistry: Uses of Power Ultrasound in Chemistry and Processing, 1st ed.; Wiley-VHC Verlag GmbH \& Co. KGaA: Weinheim, Germany, 2002; pp. 1-156.

(C) 2020 by the authors. Licensee MDPI, Basel, Switzerland. This article is an open access article distributed under the terms and conditions of the Creative Commons Attribution (CC BY) license (http://creativecommons.org/licenses/by/4.0/). 